\title{
Somatostatin Receptor Type 1
}

National Cancer Institute

\section{Source}

National Cancer Institute. Somatostatin Receptor Type 1. NCI Thesaurus. Code C18035.

Somatostatin receptor type 1 (391 aa, $\sim 43 \mathrm{kDa}$ ) is encoded by the human SST R1 gene.

This protein plays a role in neuropeptide-dependent G protein-coupled receptor signaling. 